\title{
Civil Society and Civil Islam Implementation on Inter- religious Tolerance in Indonesia: A Phenomenological Study
}

Twin Yoshua R. Destyanto ${ }^{1 *}$, Rikardo P. Sianipar ${ }^{2}$, Andreas E. Nugroho $^{3}$, and Twin

Hosea W. Kristyanto ${ }^{4}$

1,2,3,4 Prodi Magister Teologi, STTB The Way, Jakarta, Indonesia

*Corresponding author.Email: twin.destyanto@uajy.ac.id

\begin{abstract}
Civil society become a social concept that is able to help Indonesian people for living in harmony in the midst of diversity. Civil society in Indonesia upholds the synergy of democratic freedom and the use of law as a means of control and monitoring in social aspects. Later, the term civil Islam emerged, in which the Islamic leaders in Indonesia seek to incorporate Islamic values and practices into the democratic process. The implementation process has been going on for several decades. However, there are certain symptoms that indicate the degradation of public civilized values. Therefore, this study aims to investigate the process of implementing civil society and civil Islam in Indonesia, viewed from the perspective of religion sociology, which focuses on inter-religious tolerance. The study used a structured literature study and phenomenological approach. The finding shows that the process of implementing civil society has not been carried out optimally, because there is a gap between the views of implementing civil society from the majority and minorities. The gap should be a priority to be bridged to avoid religious intolerance. More understanding and application of Pancasila principles need to be strived earnestly, for the sake of inter-religious tolerance.
\end{abstract}

Keywords: civil society, civil Islam, inter-religious dialogue, religious tolerance, Pancasila.

\section{INTRODUCTION}

Indonesia is a unitary state that consists of a population with comes from various tribes, nations, and religions. The diversity in Indonesia is a product of the plurality of Indonesian people that are influenced by the geographic area, tribes, and cultures in each region, that are being harmonized by the state constitutions [1, p. 1], [2, p. 46]. This diversity condition requires a need for social concept that can accommodate the plurality. Therefore, harmony in the community can be brought into reality. For this necessity, civil society become a social concept that can help the Indonesian people for living in harmony, peace, and freedom, amid diversity [3].

Civil society terminology in the Western world showed in the $18^{\text {th }}$ century as the responses of the people to the tyrannical system [4, p. 18]. This movement developed as the hope of the people to the democracy system, which allowed all people to express their thoughts and grow as a community [5]. Uniquely, civil society in Indonesia was influenced by the Islamic background and is called Masyarakat Madani. The use of the name Madani is also associated with the event of the migration of the Prophet Muhammad from Mecca to Medina which showed the coexistence of life between Muslims and idol worshipers at that time. Madani itself is an absorption word that has a civilized meaning that emerged because of the longing of the people of Medina at that time, to become a tolerant society and freedom of religious life in diversity [6, p. 89]. Therefore, civil society involves three aspects consisting of belief, civilization, and society[7, p. 237]. Up to this point, there has been a fundamental difference between the notion of civil society adopted by the Western world and civil society born in Arabia. That is, certain aspects of belief (Islam) that are considered in Arabic civil society but not in the Western version of civil society [7, p. 241].

The concept of civil society in Indonesia in theory upholds the synergy of aspects of democratic freedom, the opportunity for the people to actively participate, and the use of law as a means of control and monitoring in 
society. This shows that civil society has a vertical aspect that shows the relationship between society and the state, as well as a horizontal one that relates to people's lives amidst diversity and tolerance [7, p. 243], [8, p. 42].

In the development of civil society in Indonesia, the term civil Islam emerged. This is a phenomenon in which the community and Islamic leaders in Indonesia seek to incorporate Islamic values and practices into the democratic and socializing process [9, p. xviii], [10, p. 6]. Civil Islam is an Islamic ethical reform project based on three principles. The first principle is the rejection of a strict separation of the relationship between religious community organizations and the government but emphasizes the separation of authority between the government and religious groups, to avoid contamination of religious ideologies by government officials $[10, \mathrm{p} .6]$, [11, p. 249], [12]. Second, civil Islam provides ethical sanctions as a differentiator between state authority and religion, except for secularists who try to reduce religious values and practices to the private sphere. In other words, civil Islam allows collaboration between the state and social life in matters related to religion $[10$, p. 6]. Third, civil Islam emphasizes that the democracy adopted is not similar to Western democracy or liberal democracy, but is more of a contemporary tool for negotiating with social differences in a world that has diverse groups and interests [13, p. 6], [14, p. 33].

The process of achieving civil society as well as the implementation of civil Islam has been going on for more than two decades since the collapse of the New Order. However, some symptoms indicate the degradation of public civilized values, such as the persistence of a corruption culture, human rights violations against religious tolerance, unlimited freedom, and the decline in authority from morality [7, pp. 243-244]. Moreover, to the best of our knowledge, the discussion about the application of civil society together with civil Islam in Indonesia is not done yet. Therefore, this study aims to investigate the process of implementing civil society and civil Islam in Indonesia, viewed from the perspective of the study of religion sociology, which focuses on tolerance between religious communities.

\section{METHOD}

To see the implementation of civil society and civil Islam in Indonesia in the study of the sociology of religion, this study used a structured literature study approach which was carried out by searching for literature references, which were related to the problems being studied in this study [15, pp. 90-91]. This structured literature study used sources from journal articles, anthology, and other articles that express opinions on any past theories. In addition, to obtain a more objective assessment, this study also used a qualitative phenomenological method, namely trying to obtain testimonies from religious sociology actors who experienced the phenomenon of the implementation of civil society and civil Islam in Indonesia [16, p. 350]. This phenomenological method was followed up by conducting interviews with three religious leaders who had experienced the implementation of civil society and civil Islam, related to religious tolerance in Indonesia.

\section{FINDINGS AND DISCUSSION}

\subsection{Implementation of Civil Society and Civil Islam in Indonesia and the Obstacles}

The implementation of civil society in Indonesia cannot be separated from the implementation of civil Islam by religious organizations. This fact is related to one of the successful parameters to the civil society implementation, namely the realization of tolerance between religious communities. Religious organizations, especially those from Islam, have participated in helping order and harmony between religious communities. Banser which is a special force for the Youth Movement (Gerakan Pemuda or GP) Ansor from Nahdlatul Ulama (NU) always participates in securing places of worship for non-Muslims, as a manifestation of maintaining tolerance between religious communities in Indonesia $[17$, p. 1].

Apart from the religious organizations, the principles of civil Islam are also applied by the Muslim community in general. For example, in Denpasar Bali, there is a location called Al-Amin alley, the majority of which are Muslims. Even though they are the majority, the residents of Al-Amin alley help each other when Hindu religious events such as Nyepi are being held. Adults and children mingle to make ogoh-ogoh to welcome the Nyepi celebration, and there are no violations that interfere with the implementation of Nyepi. On the other hand, during the implementation of halal-bihalal, Hindu residents also ask pecalang to participate in managing local security [18, p. 172]. However, it is undeniable that civil Islam that is applied excessively and is influenced by religious radicalism has an impact on the erosion of tolerance between religious communities. Radical religious organizations such as the Front Pembela Islam (FPI), which often carry out vigilantism actions against churches they consider problematic, have played a role in undermining religious tolerance in Indonesia. In addition to dealing with worship activities, in political rights, there is also intolerance towards non-Muslims who are called to become regional leaders $[19$, p. 14$]$. The notion that a gentile cannot lead an Islamic community has become the basis for cutting off this right. These things are obstacles that still occur in the process of implementing civil society and civil Islam in Indonesia in realizing interreligious tolerance. 


\subsection{Results of Phenomenological Study}

In this section, we will discuss the experiences of three religious leaders regarding the application of civil society and civil Islam in each of the resource persons. The resource persons consisted of three Christian priests and one Muslim preacher who had experience dealing with civil society and civil Islam.

\subsubsection{Respondent Pastor $G$}

Pastor G is a servant of God in the Wates area, Kulonprogo, Yogyakarta Special Region (DIY). He experienced the implementation of civil society and civil Islam in the Wates area. Pastor G thought that the implementation of civil society in his area in, particular, has not been implemented following the concept that was carried from the beginning. It is more like the majority governs the minority, because there is still a lot of discrimination based on religion. For example, in the Wates area, several times ago there was a suspension of a church's permit because the church wanted to expand its building. The church where Pastor G pastored had also experienced two threats from religious organizations, which resulted in the termination of worship activities at the church. However, the role of the government at that time, which provided a place of worship, could be a solution to this incident. According to him, these shreds of evidence showed that the civil society that was conceptualized from the beginning has not yet been realized.

Regarding the application of civil Islam, the values embedded in local norms and regulations that are Islamic (though implicitly), have not been able to help in realizing a truly civil society. The values that should be included need to be more universal and acceptable by all circles. Pastor $\mathrm{G}$ suggested holding an inter-religion discussion to formulate a more universal norm that reflects religious tolerance, as initial ideas of civil society.

\subsubsection{Respondent Pastor $H$}

Pastor $\mathrm{H}$ is a servant of God in the Bukittinggi area, West Sumatra who has pastored a church with several branches. Pastor $\mathrm{H}$ has special experiences related to the implementation of civil society in Bukittinggi. The implementation of civil society has not been fully realized in the areas where he serves. Norms that are applied as a step for the realization of civil Islam are also considered to have not succeeded in realizing a civil society in Bukittinggi. The church where he serves has received threats to be burnt three times, even though it has a church permit. Another example is his experience when residents asked to stop his Sunday worship because it was considered as an attempt to convert to Christianity. He argued that we cannot wait for civil society to be fully realized, on the contrary, we need to initialize the civil society in our environment. Even though he often experiences injustice due to religious intolerance, he still builds relationships with the surrounding community. $\mathrm{He}$ even distributes free food every Friday to the surrounding community, regardless of religious background. He often invites local children and youth to visit his house and eat together. With this approach, the residents became open to Pastor $\mathrm{H}$ and his family. This step is a manifestation of the implementation of civil society which is originally carried out by the majority.

\subsubsection{Respondent Muslim Preacher F}

Preacher F is a civil servant in Yogyakarta who is also engaged in religion, so he is trusted as a Muslim preacher in the area where he lives. According to him, the implementation of civil society in Indonesia has been going well. However, the development of technology and information in Indonesia creates a moral distortion that hinders the realization of civil society. Therefore, Preacher F told that it is necessary to re-enable the role of the family in filtering information, especially hoaxes, which can damage the morale of family members, and have an impact on the realization of civil society. Regarding the implementation of civil Islam in Indonesia, he assumes that consciously or unconsciously, every line of life in Indonesian society has implemented Islamic values. The obstacle in its implementation is that there are differences in the level of knowledge and sensitivity of everyone that affect the process of implementing Islamic law and values. This difference has made the application of civil Islam not optimal in realizing a civil society in Indonesia.

\subsection{Priorities in Overcoming Obstacles to the Implementation of Civil Society and Civil Islam in Indonesia}

Based on the results of literature and phenomenological studies of three religious leaders, the process of implementing civil society is still not optimal. Some inter-religious intolerances are still experienced by minorities. These findings are confirming that there is moral degradation on inter-religion tolerance during the implementation of both civil society and civil Islam in Indonesia [7, pp. 243-244]. The phenomenon happens because there is a gap between the implementation of civil society with the understanding of civil society understood by Indonesian people. The priority that needs to be done is to re-understand the meaning and ideas of civil society. If both the majority and the minority understand and interpret this civil society well, then every decision and attitude was taken by the people in Indonesia will reflect the ideals. The majority need to learn to accept the differences as wealth and bring out their religious values that are tolerant and loving. This will create a good impression on the reputation of the majority in society. On the other hand, for minorities who 
tend to complain because they experience injustice in the process of implementing civil society and civil Islam, there is no need to wait for civil society to be realized by the majority. Instead, this can be used as an opportunity for minorities to initiate the realization of civil society in an intolerant society.

Regarding the implementation of civil Islam, it is necessary to conduct an interfaith dialogue to formulate a more universal norm, which can be applied in both regional and central government regulations. The norms formed are expected to prevent violations of tolerance for minorities. In addition, by having dialogue in the process of formulating these norms, common ground will be obtained that supports the realization of civil society.

Moreover, the understanding of the meaning of each principle in Pancasila will also help to realize civil society. Pancasila is the original identity of the Indonesian people and the foundation for building the original concept of Indonesian civil society (Masyarakat Madani) [7, p. 250]. Therefore, if the Indonesian people diligently apply the Pancasila principles and use them as the basis for their religious activities and responses, the civil society that bring the religious-tolerance dream, will be realized soon or late.

However, the statements shared by the respondents and discussed in this study need to be confirmed to the experiences felt by common civilization (e.g. church or mosque members). Further discussion that involves the common civilizations need to be conducted to see whether any gap between spiritual leaders and civilizations' views on civil society and civil Islam implementation in Indonesia.

\section{CONCLUSION}

Based on the discussion of both the literature study and phenomenology above, it can be concluded that the process of implementing civil society has not been carried out optimally, especially in realizing tolerance between religious communities. The findings indicated by the existence of intolerant experiences both obtained from the results of literature studies and the experiences of respondents through interviews in phenomenological studies. There is a gap between the views of implementing civil society to the majority and minorities. The gap should be a priority to be bridged in the process of implementing civil society so that acts of intolerance caused by this gap can be fixed and avoided in the future. Moreover, more understanding and application of Pancasila principles need to be strived earnestly, for the sake of inter-religious tolerance. The findings of this study can be used to create certain initial topics for holding interreligious dialogue. The dialogue should discuss the phenomenon faced by both majority and minority communities related to civil society and civil Islam implementation in Indonesia.

\section{AUTHORS' CONTRIBUTIONS}

Rikardo Sianipar (RS) gave direction to write about the topic then Twin Destyanto (TD) designed the framework and did the library research. TD and Twin Kristyanto (TK) designed and did deep phenomenological interviews. Each author constructed their analysis of the collected data then together drew the conclusion and proposed certain solutions. The manuscript was done by TD and TK under the supervision of RS and Andreas Nugroho with meaningful and constructive advice.

\section{ACKNOWLEDGMENTS}

Thank LPPM STTB The Way for funding the research and the submission-related fees.

\section{REFERENCES}

[1] P. Suparlan, "Bhinneka Tunggal Ika: Keanekaragaman Sukubangsa atau Kebudayaan?,' Antropol. Indones., 2014

[2] D. O. Daeli and S. E. Zaluchu, "Analisis Fenomenologi Deskriptif terhadap Panggilan Iman Kristen untuk Kerukunan Antar Umat Beragama di Indonesia," SUNDERMANN J. Ilm. Teol. Pendidikan, Sains, Hum. dan Kebud., vol. 12, no. 2 , pp. 44-50, Nov. 2019, doi: 10.36588/sundermann.v1i1.27.

[3] F. Wajdi Ibrahim, "Pembentukan Masyarakat Madani di Indonesia Melalui Civic Education," J. Ilm. Didakt., vol. 13, no. 1, pp. 130-149, Aug. 2012, doi: 10.22373/jid.v13i1.469.

[4] T. Carothers and W. Barndt, "Civil society," Foreign Policy, pp. 18-29, 1999.

[5] J. R. Hall, Civil society: Theory, history, comparison. John Wiley \& Sons, 2013.

[6] N. Astuti, "Peran Umat Islam dalam Mewujudkan Masyarakat Madani di Indonesia," J. Ilm. Mimb. Demokr., vol. 11, no. 2, pp. 87-99, 2012.

[7] I. Charis and M. Nuryansah, "Pendidikan Islam dalam Masyarakat Madani Indonesia," MUDARRISA J. Kaji. Pendidik. Islam, vol. 7, no. 2, pp. 229-258, 2015.

[8] T. ZA, "Transformasi Teologis Politik Demokrasi Indonesia (Telaah singkat Tentang Masyarakat Madani dalam Wacana Pluralisme Agama di Indonesia)," Al-Ijtima`i Int. J. Gov. Soc. Sci., vol. 2, no. 1, pp. 41-56, Oct. 2016, doi: 10.22373/jai.v2i1.26. 
[9] R. W. Hefner, Civil islam: Muslims and democratization in indonesia, vol. 40. Princeton University Press, 2011.

[10] R. W. Hefner, "Whatever happened to civil Islam? Islam and democratisation in Indonesia, 20 years on," Asian Stud. Rev., vol. 43, no. 3, pp. 375-396, 2019.

[11] A. S. Sidahmed, “Abdullahi Ahmed An-Na'Im, Islam and Secular State: Negotiating the Future of Shari'a," Wind. Yearb. Access to Justice, vol. 29, p. 249, Feb. 2011, doi: 10.22329/wyaj.v29i0.4487.

[12] A. T. Kuru, Secularism and state policies toward religion: The United States, France, and Turkey. Cambridge University Press, 2009.

[13] R. W. Hefner, "Whatever Happened to Civil Islam? Islam and Democratisation in Indonesia, 20 Years On,” Asian Stud. Rev., vol. 43, no. 3, pp. 375-396, Jul. 2019, doi: 10.1080/10357823.2019.1625865.

[14] J. Laidlaw, The subject of virtue: An anthropology of ethics and freedom. Cambridge University Press, 2013.

[15] B. A. Habsy, "Seni memehami penelitian kuliatatif dalam bimbingan dan konseling: studi literatur," J. Konseling Andi Matappa, vol. 1, no. 2, pp. 90-100, 2017.

[16] F. Sholeh, "Penerapan Pendekatan Fenomenologi Dalam Studi Agama Islam," Qolamuna J. Stud. Islam, vol. 1, no. 2, pp. 349-360, 2016.

[17] I. Mutiah, "Peran Banser dalam menjaga toleransi umat beragama: studi pada banser kota Mojokerto tahun (2000-2019).” UIN Sunan Ampel Surabaya, 2020.

[18] I. N. Punia, N. L. N. Kebayantini, and W. B. Nugroho, "Nyepi di Kampung Muslim Al-Amin: Leksikon Dinamika Sosial Toleransi Beragama di Denpasar, Bali," J. Kaji. Bali (Journal Bali Stud., vol. 8, no. 1, pp. 159-180, 2018.

[19] I. Madid, "Dinamika Pemikiran Nahdlatul Ulama dalam Merespons Kepemimpinan Non Muslim di Indonesia," J. Ilm. Mizani Wacana Hukum, Ekon. Dan Keagamaan, vol. 6, no. 1, p. 13, Aug. 2019, doi: 10.29300/mzn.v6i1.2197. 